\title{
ECONOMICS OF ORTHODOX TEA PRODUCTION: A CASE OF ILAM, NEPAL
}

\author{
A. Tiwari ${ }^{1}$, K.B. Adhikari², S.M.Dhungana ${ }^{3}$
}

\begin{abstract}
Research on economic analysis of conventional orthodox tea in llam district of Nepal was conducted by selecting Fikkal and Kanyam area of Suryodaya Municipality purposely. The average area under tea cultivation was 0.67 hectares per household in Fikkal area and 0.57 hectares per household in Kanyam area. The average productivity of green leaf in Fikkal area was found slightly higher than Kanyam area. The average cost of green leaf production per ropani in Fikkal area was found higher than Kanyam area. It was more in small category compared to large category in both study area. This signified the principle of economies of scale. Gross margin per hectares was positively correlated with increased farm size in both the study areas. Overall benefit-cost ratio was greater than one in both the study areas. The study revealed the scarcity of quality inputs and inadequate technical knowhow, quick perishability of green leaf, price instability, and unavailability of auction market, weak horizontal coordination and vertical coordination at the different stages of tea value chains were the major problems in the study area.
\end{abstract}

Keywords: Benefit-Cost ratio, Conventional, Economies of Scale, Gross margin.

\section{INTRODUCTION}

Agriculture sector in Nepal contributes about 30.13 percent share in the national Gross Domestic Product (GDP), whereas tea sector contributes about 0.0105 percent in the National Gross Domestic Product (NGDP) and 0.0347 percent in the Agricultural Gross Domestic Product (AGDP) (CBS, 2014). Agriculture has to be a key sector that has to be developed and commercialized to raise the living standard of rural people by providing employment opportunities (Adhikari, 2000).

Among the cash crops, Orthodox tea is a major cash-generating crop in the eastern hills (Jha, 2004). Orthodox tea is mainly destined for overseas market. About 96 percent is exported to America, Germany, Japan and the EU and remaining 4 percent is consumed in the country by the foreign tourists and wealthy families inside Nepal (Poudel, 2010). The new agriculture plan of Government of Nepal, Agriculture Development Strategy (ADS) has also given the due importance in commercialized farming and processing activities of high value cash crops like tea (MoAD, 2015).

\section{OBJECTIVES}

- To determine the economics of orthodox tea production.

- To determine the profitability of orthodox tea production.

Major author, M.Sc. Ag (Agricultural Economics), Agriculture and Forestry University, tanup4078@gmail.com Reader, Department of Agricultural Economics and Agribusiness Management, Agriculture and Forestry University Assistant Professor, Department of Agricultural Economics and Agribusiness Management, Agriculture and Forestry University 


\section{METHODOLOGY}

A sample size of 70 tea growers, 35 each from Fikkal and Kanyam area were selected using simple random sampling method. This study was also conducted to analyse the different aspects of economics of production of green leaf based on the scale of production. This is why categorization of tea growers was done. This categorization was done based on the suggestion from NTCDB staff (Pokhrel, 2006).

Tea growing farmers, tea processing factories and local collectors were the major sources of primary data. Besides this, information was obtained through observation, focus group discussion (FGD) and key informant surveys. The primary and secondary information collected from the field surveys and different other methods were coded, tabulated and analysed by using Statistical Package for Social Science (SPSS) and Microsoft Excel.

The gross margin provides simple and quick method of analysing a farm business. For any enterprises gross margin is the difference between the gross return and the variable cost incurred. The variable cost must be specific to single enterprise and vary approximately in proportion to the size of the enterprise (Shankyan, 1983).

The gross margin of the tea growers in this study was calculated as:

Gross margin $=$ Gross return- total variable cost

Gross return $=$ Green leaf sold $(\mathrm{kg}) \times$ per unit price of green leaf $(\mathrm{NPR} / \mathrm{kg})$.

Total variable cost $=$ Summation of all variable cost items

Benefit-cost analysis was carried out by using following formula;

$\mathrm{B} / \mathrm{C}$ ratio $=$ Gross return $/$ Total variable cost

\section{RESULT AND DISCUSSION}

The category wise distribution of area under tea cultivation and production in Fikkal and Kanyam area is presented in Table 1. The average land under tea cultivation per household in small category of Fikkal area $(0.30 \mathrm{ha})$ was found lower than in Kanyam area $(0.31 \mathrm{ha})$. However, in large category, opposite case was found. The average production of green leaf per household was found higher in Kanyam area $(5390.86 \mathrm{~kg})$ than Fikkal area $(4410.00 \mathrm{~kg})$.

Table 1: Average area/household, production and productivity by farm categories and study area

\begin{tabular}{c|cccccc}
\hline \multirow{2}{*}{ Farm Category } & \multicolumn{4}{|c}{ Fikkal } & \multicolumn{2}{c}{ Kanyam } \\
\cline { 2 - 7 } & Area (ha) & Productn (kg) & Productivity (kg/ha) & Area (ha) & Production (kg) & Productivity (kg/ha) \\
\hline Small & 0.30 & 2502.17 & 8340.57 & 0.31 & 2221.25 & 7165.32 \\
Large & 1.21 & 8725 & 7210.74 & 1.20 & 10244.12 & 8536.77 \\
Area average & 0.76 & 4410.00 & 7775.66 & 0.76 & 6232.69 & 7851.05 \\
\hline
\end{tabular}

Source: Field Survey, 2015

The average productivity was found increasing as the farm size increased from small to large in Kanyam area and in Fikkal area, it decreased slightly as the farm size increased from small to large. 
Average productivity in Kanyam area was $7851.05 \mathrm{~kg} / \mathrm{ha}$ and $7775.66 \mathrm{Kg} / \mathrm{ha}$ in Fikkal area (Table 1). The positive correlation between average productivity and farm categories was found in Kanyam area whereas it was found negative in Fikkal area. This may be due to the more amount of inputs and well managed tea plantation done in the increasing farm size in Kanyam area and in the Fikkal area, as the farm size became large the productivity decreased due to better management and more inputs used in the initial years of tea plantation by large farmers and in the later years improper management and less supply of labors by the large farm. Small farmers in the Fikkal area were found providing proper and constant management in all the year of tea plantation with efficient use of family labors and variable inputs.

Study showed that the average per hectare cost of green leaf production in Fikkal area (NPR 401.3735) was lower than Kanyam area (NPR 404.585). SNV (2010) reported that the cost of green leaf production was NPR 19.55 per $\mathrm{Kg}$ under the conventional cropping methods based on production yield of green leaf to be around 2.75 metric tons per year in a land of 0.5 ha. The cultivation cost was NPR 15 per $\mathrm{Kg}$ of green leaf while the manufacturing cost of orthodox tea was NPR 199 per $\mathrm{kg}$ of made tea (Thapa, 2005). The average cost of production in small farm was found higher compared to large farm category in both the study area (Table 2). This was due to more family labors used by small farmers and less amount of inputs used by large farmers.

Table 2: Average variable cost of green leaf production by farm categories and study area

\begin{tabular}{c|ccc|c}
\hline \multirow{2}{*}{$\begin{array}{c}\text { Farm } \\
\text { category }\end{array}$} & \multicolumn{3}{|c}{ Fikkal } & Kanyam \\
\cline { 2 - 5 } & Cost(NPR/ha) & Cost(NPR/kg) & Cost(NPR/ha) & Cost(NPR/kg) \\
\hline Small & 464.2345 & 23.11 & 428.8965 & 23.67 \\
Large & 338.5125 & 18.16 & 380.2735 & 18.61 \\
Area average & 401.3735 & 21.41 & 404.585 & 20.92 \\
\hline
\end{tabular}

Source: Field Survey, 2015

Average income from green leaf production was found higher in Fikkal area because of higher productivity. The higher income per $\mathrm{kg}$ of green leaf produced was due to higher price paid by processing factory in Fikkal area. Average income per hectare and per $\mathrm{kg}$ price among farm categories in the study areas is presented in Table 3.

Table 3: Average income from green leaf production by farm categories and study area (2015)

\begin{tabular}{c|cccc}
\hline \multirow{2}{*}{ Farm category } & \multicolumn{2}{|c}{ Fikkal } & \multicolumn{2}{c}{ Kanyam } \\
\cline { 2 - 5 } & Income (NPR/ha) & Price (NPR/kg) & Income (NPR/ha) & Price (NPR/kg) \\
\cline { 2 - 5 } Small & 671.9595 & 31.69 & 540.4145 & 29.56 \\
Large & 649.7925 & 31.94 & 646.977 & 30.39 \\
Area average & 660.876 & 31.78 & 593.69575 & 30.01 \\
\hline
\end{tabular}

Source: Field Survey, 2015 
The per hectare gross margin and per kg gross margin of Fikkal area was found higher than Kanyam area. This was because of higher productivity in Fikkal area than Kanyam area.

Gross margin in large farm category was found higher than the small categories in both the study areas. This was because the total variable cost being lower in large farm category. This signifies the economies of scale. The gross margin analysis of different farm categories in both the study area is presented in Table 4. In case of Orthodox tea cultivation of 12 years age, annual average gross return and average net return from one hectare area was NPR 1,86,000 and NPR 1,11,000 respectively (DAARD, 2001).

Table 4: Gross margin analysis of green leaf production by study farm categories and study area

\begin{tabular}{cc|cc}
\hline Study area & Farm category & Gross margin (NPR/ha) & Gross margin (NPR/kg) \\
\hline Fikkal & Small & 207.725 & 8.59 \\
& Large & 311.2795 & 13.78 \\
& Area average & 259.50225 & 10.37 \\
\multirow{2}{*}{ Kanyam } & Small & 111.518 & 5.89 \\
& Large & 266.7035 & 11.78 \\
& Area average & 189.11075 & 9.09 \\
\hline
\end{tabular}

Source: Field Survey, 2015

The benefit cost ratio of Fikkal area (1.74) was found higher than Kanyam area (1.70) which signified good profitability of green leaf production in that area. Pokhrel (2006) also reported B/C ratio greater than one in Fikkal and Jasbire area of Ilam district.

Table 5: Benefit cost analysis of green leaf production by farm categories and study areas

\begin{tabular}{cc|ccc}
\hline \multirow{2}{*}{ Study area } & Farmer category & $\begin{array}{c}\text { Average revenue } \\
\text { (NPR) }\end{array}$ & Average variable cost (NPR) & B/C ratio \\
\hline \multirow{2}{*}{ Fikkal } & Small & 79731.88 & 53885.00 & 1.48 \\
& Large & 257638.89 & 133259.17 & 1.93 \\
& $\begin{array}{c}\text { Area wise } \\
\text { average }\end{array}$ & 140728.57 & 81099.00 & 1.74 \\
\multirow{2}{*}{ Kanyam } & Small & 66094.58 & 51068.75 & 1.29 \\
& Large & 244719.29 & 137110.53 & 1.78 \\
& $\begin{array}{c}\text { Area wise } \\
\text { average }\end{array}$ & 163062.29 & 97777.14 & 1.67 \\
\hline & 151895.43 & 89438.07 & 1.70 \\
\hline
\end{tabular}

Source: Field Survey, 2015 


\section{CONCLUSION}

The research study was aimed at finding out the economics of production of the orthodox tea in Ilam, Nepal. The result of this research shows that Nepalese orthodox tea has the potential and competitive advantage of being an agricultural export product, which has already established its way to the international markets.

Orthodox tea production is one of the profitable enterprises. Contribution of green leaf orthodox tea production to household economy of the rural masses is significant. This enterprise creates selfemployment to large rural masses in our country. The marginal sloppy hilly areas of eastern part of Nepal are suitable for growing high quality orthodox tea. The study indicated that the conventional orthodox tea production could emerge as a better tool to reduce poverty in eastern mid hills of Nepal and would recognize the country in the international arena by exporting orthodox tea with its brand name or logo.

\section{REFERENCES}

Adhikari, K. P., 2000. Study of Socio- Economic Impact of Vegetable Seed Production in Khalanga Village Development Committee, Rukum.Annual Report. HMG, MOAC. DOA and Vegetable Seed Production Centre, Rukum, Nepal.

APROSC \& JMA,1995. Nepal Agriculture Perspective Plan (APP) Summery Document: APROSC Kathmandu, Nepal and John Mellor Associates, Inc.

CBS, 2014.Statistical year book of Nepal.Central Bureau of Statistics. National Planning Commission Secretariat, Government of Nepal. Kathmandu, Nepal.

DAARD, 2001. Poverty Alleviation through Development of Tea Sector in Nepal. Baseline Study on: Orthodox Tea Production in Eastern Hills District of Nepal. Development Associates for Regional and Rural Development. Kathmandu, Nepal.

Jha, A.K., 2004. Status of Tea cultivation Practices In the Eastern Hills of Nepal. In: Advances of Horticultural Research in Nepal.Proceedings of The Fourth National Workshops On Horticulture. Held on March 24, 2004. Organized by Nepal Agriculture Research Council, National Agriculture Research Institute and Horticulture Research Division Khumaltar, Lalitpur, Nepal.

MoAD, 2015.Statistical Information on Nepalese Agriculture.Ministry of Agricultural Development, Agribusiness Promotion and Statistical Division and Agriculture Statistics Division.Singha Durbar, Kathmandu, Nepal.

Pokhrel, P., 2006. Economic Analysis of Orthodox Tea in Ilam disrtict of Nepal. Msc. Disertation submitted to Institute of Agriculture and Animal Science, Rampur, Chitwan, Nepal.

Poudel, K., 2010. Orthodox tea production and its contribution in Nepal. The Third Pole 8-10:34-42.

Sankhyan, P. L., 1983.Introduction to farm management. New Delhi:Tata Mcgrow-hill Publishing Co.

SNV Nepal, 2010.Adding value to Nepal's Orthodox Tea Industry. Lalitpur, Nepal: SNV

Thapa, Y. B., 2005. Commodity case study tea. In: Karkee, M.K., \& Sharma, R.P. (eds.), Implications of the WTO Memberships on Nepalese Agriculture. Food and Agriculture Organization of the United Nations, Kathmandu, Nepal. 